\title{
Writing in Exile: Bidoon Resistance and Speaking Truth to Power
}

\author{
Areej Alshammiry \\ University of Alberta \\ alshammi@ualberta.ca
}

\begin{abstract}
This article concentrates on the writings of the late Naser Al-Zafiri who documented the realities of the Bidoon community's experiences in Kuwait and the diaspora. In his novels, through the detailed portrayals of the characters and their stories, Zafiri explicates lived experiences of belonging and homelessness of the Bidoon in Kuwait, as well as their immigrant experiences and encounters in Canada and other countries. By illustrating the pedagogical and political significance of Zafiri's novels, and situating it in relation to other resistance work, the article contributes to our understanding of truth-telling, resistance, resiliency and survival of the Bidoons in Kuwait and in the diaspora.
\end{abstract}

Keywords: Diaspora, Bidoon(s), Stateless(ness), Exile, Belonging, Homelessness, Citizenship

\section{Introduction}

This article presents an account of Naser Al-Zafiri and his literary work. It also provides an overview of the conditions of statelessness globally and in Kuwait. It then explicates forms of resistance among the Bidoon in Kuwait and in the diaspora through various pedagogical strategies. Finally, it pays closer attention to the significance of Zafiri's novels as a form of resistance to power operating in knowledge production in Kuwait. The term Bidoon is a colloquial term in Arabic meaning without, as in 'Bidoon Jinsiya' [without nationality]. It is also used to informally signify a person who is stateless in Kuwait. Due to the close connection between the two terms, I use Bidoon and stateless interchangeably throughout this article.

Oppositional storytelling is a powerful form of pedagogy in the face of power structures which operate and control official knowledge. Official knowledge production operates in order to render false information as truth and facilitates other structures of domination such as law and politics. Narratives of dominated people have the potential to challenge dominant single narratives, empower groups, and connect them across space and time in order to tap into and mobilize new forms of political imagination. The stories act as a witness of the history of the oppressed by documenting their collective social experiences through the individuals' accounts. Accordingly, the stories become a tool for emancipation because of the power of authenticity that they carry. The stories also demonstrate individual perceptions and experiences of public issues. In such cases, histories are interpreted by the memory and imagination of the writer(s) in order to help develop and legitimate the collective consciousness. In reality, such works create spaces for people living in diasporas after being forced to migrate because of wars, environmental crises, and other man-made problems, including statelessness. 
I focus on the condition of statelessness in this article because I myself was born stateless in Kuwait before migrating to Canada with my family for citizenship. I shed light on this condition in this article through my discussion of the late Naser Al-Zafiri's novels because he focussed on statelessness in ways that captured its lived realities, including experiences after citizenship acquisition in another country like Canada. Zafiri's novels resonated with some of my experiences as a former stateless person now living in the diaspora. After years of feeling isolated and not having the space to share my experiences or finding writing that spoke to it, I have come to connect with other Bidoons across the world through Zafiri's novels, and other Bidoon literature.

Zafiri was a renowned novelist from the stateless community in Kuwait. He left Kuwait with his family as stateless refugees and settled in Canada in 2001. He spent his years writing about the Bidoon in his novels before he passed away in March of 2019, after a battle with cancer. Zafiri was a close friend of my father's. As diasporic Bidoons living in Canada, they shared the dreadful sense of exile from and nostalgia for Kuwait. I had planned to meet Zafiri for my research to hear about his writing, especially his experiences of being a former stateless person who adopted Canadian citizenship. His writing resonated with so much of what I and many other Bidoons experience, in our exilic life, as we search for belonging.

Zafiri utilized his writing about statelessness, identity and belonging as a form of resistance to the Kuwaiti state's official narratives. The state's narratives continue to promote false stories about the Bidoon and their histories. They also negate the Bidoon's associations with the land in Kuwait through a long process of denationalization. To counter these narratives, some of the Bidoon in Kuwait and in the diaspora document their experiences and interpretations of their exilic worlds through creative works such as novels, memoirs, autobiographies, poetry and art, others through social media. These stories are recounted in the first person or through fictional characters based on true stories. I use these connections to build my argument concerning the political significance of these works for the Bidoon.

The government labelled the Bidoon as "Illegal Residents", in 1986, arguing they are foreigners who destroyed their documents and claim to be nationals of Kuwait (BBC Arabic, 2020; HRW, 1995, p. 7). Such labels render the Bidoon as outsiders to the very land that they and their ancestors have lived on for a very long time. These negative, emotive and one-sided, distorted narratives continue to shape public consciousness and unfortunately, inform the policies that aim to marginalize the Bidoon. Furthermore, these policies justify the state's abilities to continue to enforce the Bidoon's conditions of being stateless. By adopting several arbitrary strategies, the government deliberately blocks all attempts to recognize the validity of the Bidoon's claims, to rewrite their own histories, and to explain their lived realities. However, many Bidoons continue to challenge dominant discourses through literature and art.

\section{Statelessness: A Summary}

\section{Global Statelessness}

There are at least 10 million stateless people in the world (UNHCR, 2013; ISI, 2018). Statelessness has been receiving growing attention in the last ten years by academics and international organizations. In fact, most stateless populations lack citizenship/legal identity

Cultural and Pedagogical Inquiry, Summer 2020, 12(1), pp. 149-164

ISSN 1916-3460 @ 2020 University of Alberta

http://ejournals.library.ualberta.ca/index.php/cpi/index 
because they constitute a minority group that faces direct, covert and systematic discrimination and oppression by the state they exist in (Kingston, 2019). This leaves many of them unprotected and vulnerable to devastating and dehumanizing conditions. Many states weaponize documentation as a tool to marginalize certain communities (Siddiqi, 2019), which makes statelessness a common condition for oppressed peoples around the world.

Surprisingly, there is still an emphasis in dominant literature on statelessness situating it within paradigms of original membership, forced displacement and voluntary movements (Cole, 2019). Unfortunately, these frameworks obscure how many individuals have been subjected to the weaponization of the state's immigration and citizenship policies which can be tools for exclusion and/or displacement. Furthermore, the original membership paradigm has the effect of shaping policies, legal reforms and scholarly work in ways that assume that every human naturally belongs to a state. It treats nation-states and borders as being natural and having always existed, thereby, erasing ancient representations of human life and indigenous ways of being to assert modern forms of colonial legal establishments. Moreover, these paradigms assume that having citizenship of a country translates into a sense of belonging, and ignore the challenges and structures of oppression that people face, despite having citizenship that relate to other categories of identity such as race, gender, class, religion, etc.

Additionally, these paradigms are limited in addressing the structural causes that produce statelessness in places where it is produced within borders as a result of deliberate exclusion of a particular population; e.g. the Rohingya in Myanmar, Haitians in the Dominican Republic, and Bidoons in Kuwait. Such assumptions can have dire effects on stateless populations and host states by prolonging adequate solutions to prevent statelessness and allowing the continuation of individuals living in poor and destitute conditions. Stateless populations lack many rights such as access to healthcare, education and employment. They are also subject to various types of violence such as labor exploitation, sexual and physical assaults, childhood marriage, human trafficking, forced displacement, and many types of psychological damage.

Despite efforts to include stateless voices in some scholarship and activism, the literature and policies implemented continue to be dominated by the voices of people who have not experienced statelessness. It is often a result of the severe marginalization that stateless population's experience that hinder them from reaching positions of knowledge production or policy-making, and even challenges in traveling. Nevertheless, there are many stateless individuals who are determined to advocate and document their stories of statelessness. Zafiri and others I mention later in the article are examples of such individuals in the Kuwaiti context.

\section{Statelessness in Kuwait}

Over 100,000 stateless people live in Kuwait, known as the Bidoon, constituting about $10 \%$ of the Kuwaiti national population. There are estimates the actual number exceeds 200,000 excluding those who have been exiled or migrated to other countries for citizenship (HRW, The Bedoons of Kuwait: "Citizens without Citizenship", 1995). Bidoon, as a category, does not only signify one who is stateless in Kuwait. As political subjects of the Kuwaiti nation-state, it connotates much more than the legal status it holds. Before the term existed, Bidoons were known by their tribal background and affiliation as Arab Bedouins. Over the years, specifically since 1959, the Bidoon's material and ideological conditions have developed in ways that separated them ideologically and ontologically, from the Kuwaiti citizen body, into existentially Cultural and Pedagogical Inquiry, Summer 2020, 12(1), pp. 149-164

ISSN 1916-3460 @ 2020 University of Alberta http://ejournals.library.ualberta.ca/index.php/cpi/index 
a different class and ethnic group (Beaugrand, 2014). This was enabled through shifting deliberately their legal classifications; marginalizing them into isolated social and physical realms; erasing their historical conditions of existence and ties with the land; and painting them as 'unlawful' people through state propaganda.

The majority of Bidoons derive from a Northern nomadic tribal background. These tribes traveled and resided in the deserts of the Arabian Peninsula for generations, prior to the establishment of the modern nation state of Kuwait. The Kuwait's nationality law was established in 1959. Between 1959 and 1965, committees for nationality registration took place in the town where Kuwaiti urban settlement took place in the early years, and which now constitutes Kuwait City and what is known as Al-Asimah governorate. While some tribes who settled in the suburbs were naturalized, the rest were excluded from this process for residing far in the desert. While dominant literature on the Bidoon specify that the reasons for exclusion were because they lived far away in the desert areas and were unaware of the required registration process, or 'failed' to register, there are other reasons that contributed to their exclusion that are ignored in the official literature.

First, their inability to provide formal proof of their residence within Kuwait's borders during the process of citizenship registration, supported the official state discourses that Bidoons were not present on the land and only crossed the borders later on, intentionally to pursue nationality in Kuwait. Second, at some point, witness testimonies or affidavits were a necessary part of the registration process. Unfortunately, some Bidoons were unable to bring witnesses to affirm their presence on the land and their affiliation through trade or social relations with nationals in the city. Third, some Bidoons who tried to register later were offered second-class citizenship. They refused because it was discriminatory and established a hierarchy of citizens. Finally, some people simply refused the need to have official documentation and the creation of state borders because it went against their traditional ways of living and being nomadic tribes.

Within a span of 50 years, the government changed the classification of the stateless community from "Kuwait's tribes", to "Without Nationality" (the source of the term Bidoon), to "Undetermined Nationality" and lastly, "Illegal Residents" (Beaugrand, 2014). The shifts in the classifications of Bidoons demonstrate the intentional erasure of their histories by the state authorities. The classifications homogenized the Bidoons into one legal category which erased their diverse backgrounds. This stripped them of their agency and autonomy as diverse nations that have long resided on the lands, and indeed, created a new ontological status for them that fitted well within the legal frameworks of the sovereign state.

Currently, stateless people in Kuwait face systematic oppression by the Kuwaiti government, led by its Central System for the Remedy of the Situation of Illegal Residents (Central System henceforth). This administration was established in 2010 by a royal decree as the latest independent entity of the state following previous administrations that failed to 'end statelessness' in Kuwait. The goal of this administration is to solve the 'problem' of statelessness that the government has been dealing with for years (Beaugrand, 2017, p. 36). Nevertheless, the conditions that the Bidoon live in have deteriorated even more after the new administration was created. The Central System has been deliberately oppressing the community through stripping Bidoons of their basic human rights and services such as access to public education, health care, secure employment, documentation, mobility, etc. (Beaugrand, 2017, p. 135). In order to renew 
their identification cards and to access basic services, the Bidoon have to agree to blindly sign documentation which groups them with other nationalities. The Central System has used this tactic to forge 'proof of citizenship' for some of the Bidoon who agree to support the government's claims that they are "Illegal Residents". Denying Bidoons' statelessness enables the government to avoid responsibility under international law to naturalize them (Beaugrand, 2014). Nonetheless, as a form of resistance, many Bidoons have boycotted the Central System.

Ongoing violence and failed attempts to achieve state recognition has forced thousands of Bidoons to migrate to other countries for citizenship purposes. Many migrated to England, Australia, Canada, and other countries. In addition, many others were exiled after the Gulf War, because the government banned their re-entry or deported them. Thus, a large community of Bidoons live in the diaspora. However, the official literature on Bidoon statelessness largely ignores them. Most of the writing focuses on the conditions of Bidoons in Kuwait with some references to their migration. Little to nothing discusses their experiences post-migration. Accordingly, I focus on Bidoons in the diaspora in my research and discuss Zafiri's writing in this article.

\section{Naser Al-Zafiri's Literary Work \\ "وطني هو إعاقتي الأبدية الوحيدة التي لن أشفى منها أبدا" ـ كاليسكا" \\ "Home is the one eternal illness that I will never be healed from" - Kaleeska}

This was Zafiri's dramatic opening quote in his novel Kaleeska, published in 2015, which explored such themes as exile, identity loss, racism, classism, love, and hate. Indeed, Zafiri's depiction of homelessness was obvious in all his characters' stories. Homelessness and exile can have a variety of meanings, but here I use them to describe a sense of rooted displacement that illustrates how stateless people, in particular, experiences a complex uncertainty that surrounds their belonging when they are non-citizens everywhere. Their sense of identity and belonging become ambiguous and their exclusion by their state of birth displaces them internally (Belton, 2015). Moreover, this confusing state may become entangled with the physical experiences of migration and displacement that can further complicate their existing feelings of exile, because migration adds layers of complex issues around identity and belonging. This is the case for many Bidoons who migrate to other countries for citizenship and belonging.

Zafiri was born in the city of Jahra in Kuwait, in 1960. He completed his elementary and high school education and graduated in 1978. The government did not allow Bidoons to enter post-secondary education at the time, and the only option for Bidoon men was to enlist for the armed forces. In 1982, two years after he joined the army, the government passed a bill allowing Bidoons to continue their post-secondary education. Zafiri applied and was admitted to the College of Civil Engineering at Kuwait University. During his time there, he co-founded a cultural student club with other students who were interested in literature and poetry. He also became a journal editor for the university's cultural magazine called Afaq. Zafiri published his first short story in 1987, in the Al-Watan newspaper, and continued publishing other stories in local and regional Arab magazines. He graduated with a Bachelor's Degree in Engineering in 1987 and returned to the army as a full-time job. In addition, he worked part-time as a journal 
editor at Al-Watan in the evenings. As part of his commitment to truth-telling, Zafiri began publishing a series of stories which marked the beginnings of his writing incorporating political and social insights about statelessness and the Kuwaiti society.

Through his fictional characters, Zafiri wrote novels that discussed statelessness. He shed light on the experiences and stories that he knew about Bidoons, including his own experiences. The works explored several interconnected themes which highlighted the contradictions associated with being an exile on your own land. After Zafiri's emigration to Canada, his novels incorporated a new reality; his life in the diaspora and his new perceptions of identity, home(lessness) and belonging.

Zafiri centered the spatiotemporal dimensions in his novels to emphasize the significance of place and land on the lives of Bidoons. He made constant references to the desert, where most Bidoons' ancestors had lived. A part of this land has become an urban establishment in today's Kuwaiti nation-state. Zafiri expressed through his characters, like Ali bin Shoman in Al-Sahd (2013), how contemporary Bidoons' realities relate to a time of nomadic life in the deserts of the Arabian Peninsula. He often placed the characters' stories in Al-Jahra, one of the six governorates in Kuwait, and where the Taima' City is located. (See illustration below).

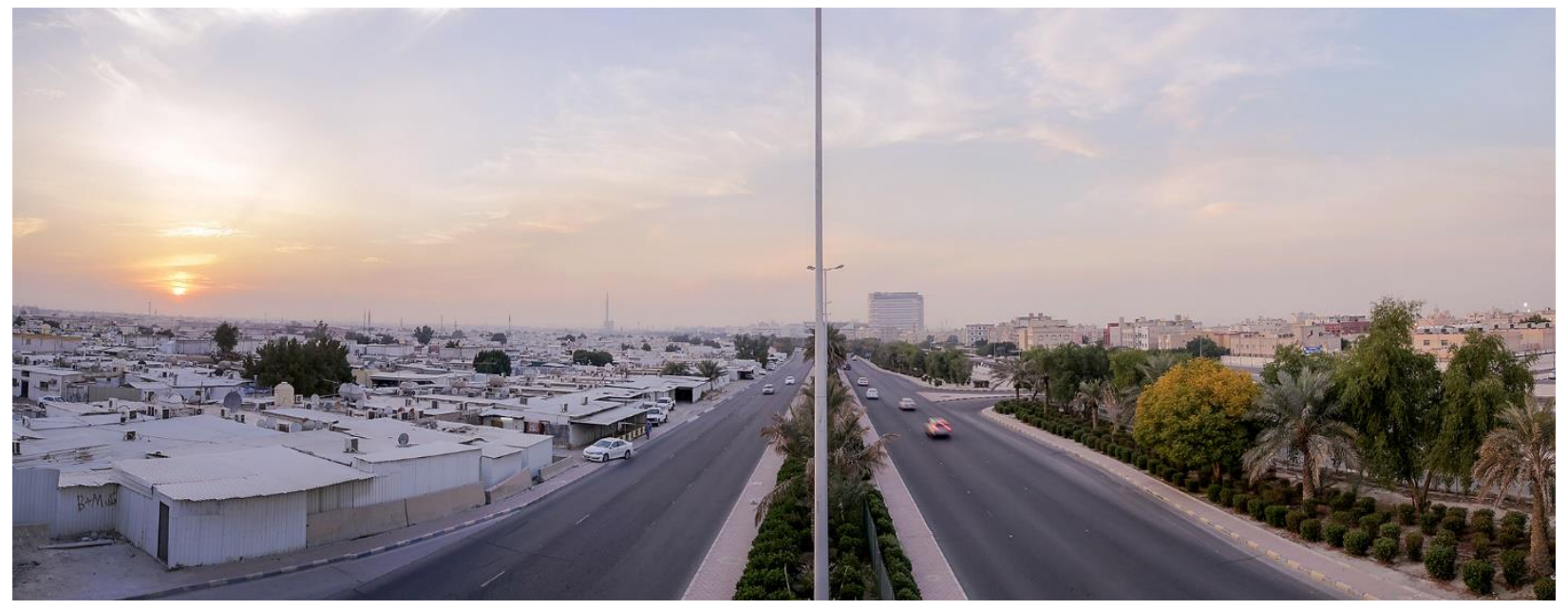

Taima' City (Left), Al-Naeem (Right), Province of Jahra (Photo taken by Bilal Al-Fadli)

Taima' is a disenfranchised city with slums in which one of the largest numbers of Bidoons live (Beaugrand, 2017). Zafiri's novel described the architectural details of the city's shanties, and further, how they shaped the day-to-day lives of Bidoons. The centering of Taima' symbolized a significant discrepancy and inequality in the social and economic structure of Kuwait. Taima's slums, for example, are located right across the road from Al-Naeem (which ironically translates to paradise), another modern city in Al-Jahra with medium rise buildings, mostly inhabited by citizens. The photograph above shows the significant spatial and political contrast between the two cities. Situating places, as a main aspect of the novel, enabled Zafiri to discuss the relationships between Bidoons' identity crises, sense of belonging and the land. He shared the stories of Bidoons who were born and raised in Al-Jahra, living the paradoxes of 
belonging due to their exclusion from citizenship, and various significant, social, economic and political spaces in Kuwait. Al-Jahra not only symbolized the urban peripheries of the nationstate, but also the casting of the Bidoons into the margins of all aspects of life. A year before he passed away, Zafiri posted the above photo on his Twitter account and described it as: "the line between 'Paradise' and 'Hell's Taima'." He emphasized that "this bridge is the difference between a life for normal humans in paradise, and the inhumane life of the oppressed and marginalized enforced on Bidoons, despite the small distance between both cities" (Personal conversation with one of Zafiri's friends, May 16, 2020).

Zafiri emphasized how the sense of homelessness in one's place of birth is never gone. Even if Bidoons find recognition and acceptance elsewhere, feeling like an exile becomes part of their identities. He seemed to realize that Bidoons suffer from a chronic sense of homelessness. In Sama Maqlooba (1995), he ended the novel with his main character (about to depart from Kuwait to Canada), stating emphatically: "I left nothing heading towards nothing. Nothing but the idea of escaping, and what makes me hold on are those who have escaped there ahead of me." Zafiri endorsed migration as the Bidoon destiny, taking his characters' stories to other countries, but mostly to Canada (being familiar more with it). It is like descending from nomadism where one does not belong to a specific territory or place, only to live an exilic life in another country, where no territory feels like home. Home is a place only in the imagination.

Writing after migration, Zafiri expressed a sense of homelessness and nostalgia for a place that could never be found, and memories of a place that caused despair. Zafiri authored several additional novels that incorporated stories of diasporic Bidoons. In his novel Kaleeska (The Coyote), the main character (Al-Awad) falls in love with a woman (Rasha) from a different and more powerful class than his. Her brother (Abdulrahman) rejects Awad and punishes him for daring to love Rasha. Abdulrahman revoked Al-Awad's citizenship, humiliated his uncle in front of him (who was like a father to him), imprisoned him, before deporting him to Syria. Awad was imprisoned in Syria by another violent regime. He suffered for some time before he fled, as a refugee, to Canada. Awad makes it as his life's mission to seek revenge on the man who destroyed his life. Zafiri takes us on a thrilling journey in this story, showing readers how vengeance has eaten Awad alive and affected his new life and relationships in Canada. Awad meets another woman in Ottawa named Stefanie, whom he is unable to love because he was still living with the memory of his life in Kuwait and his love for Rasha. Eventually, Awad reunites with Rasha in Canada. He uses her to lure her brother Abdulrahman. Awad takes him into the woods, in the middle of a cold Canadian winter, leaving him to die. The story ends with Awad ready to face the consequences of his decisions, in court, feeling devastated and lost. Zafiri leaves the story with an open ending. Awad is in despair and trying to decide whether he loved Rasha or Stefanie.

Zafiri's novels addressed socio-political issues in Kuwait like 'original membership' and 'authentic citizenship', which are key points in debates concerning nationality in Kuwait. These issues underpin much of the discussions on Bidoon's right to citizenship. For instance, the painful love story in Kaleeska symbolizes the class struggles in the Kuwaiti society. Zafiri used this novel to shed light on the kinds of injustices related to the regime in Kuwait (during and after its foundational years as a modern state), and how it affected various people, but specifically Bidoons.

\footnotetext{
${ }^{1}$ Link to tweet here: https://twitter.com/nalzafiri/status/961677577520930822?s=20

Cultural and Pedagogical Inquiry, Summer 2020, 12(1), pp. 149-164

ISSN 1916-3460 (C) 2020 University of Alberta

http://ejournals.library.ualberta.ca/index.php/cpi/index
} 
It speaks to the ways in which the social foundations of the nation are comprised of various hierarchies and tensions. These include ethnicity, conflicts between tribalism and modernity, and a nationalism that ranks people based on citizenship class and so- called 'authentic Kuwaiti'. Zafiri addresses these matters in terms of Abdulrahman's insecurities about his citizenship class. Abdulrahman originated from an Iraqi background and was naturalized after his father settled in Kuwait for work purposes. He grew up facing constant intimidation and made to feel inferior to other Kuwaitis who were biased against those with Iraqi affiliations (Beaugrand, 2017). But ultimately, he became a powerful man with influence because he married into a merchant family. Representing a lower class of citizenship, Awad reminded Abdulrahman of his background and triggered his internalized hate and view of the 'other', leading him to aggression.

Zafiri's work illustrates the exilic realities of Bidoons who migrated to other countries. Many Bidoons continue to live in the memory of where they come from, unable to let go of their attachments, and struggle to fully settle into their new lives. Before one comes to a country, one leaves a country, but the ties linger on - those of music, religion, food, language, rituals, holidays and much more. Thus, leaving never really means one has left. This constant linking back to 'home' is part of the diasporic reality. The love triangle Awad was stuck in, in Kaleeska at the end of the story, exemplifies the challenging relationship with the country he loved but denied him recognition and acceptance and created a lifetime of trauma. Ironically, the country that recognized him as a citizen and offered him better chances, still felt to be less of a home. In my conversations with several diasporic Bidoons in Canada, and other Western countries over the years, I have found this experience common among many of us. They experience a homeland where they do not fully fit in, leading to a sense of loss. They live in between identities, permanently in flux. As Meenakshi Thapan (2005) describes it in her work on transnational migrants: "they are locked in an inextricable state of being and becoming, simultaneously inhabiting two or more worlds, always living in psychological despair" (p. 31). The hold of one's place of birth is especially true for the first generation of Bidoon migrants, who left Kuwait during their adulthood, taking so many memories with them.

\section{Bidoons’ Resistance: Literature, Social Movements, and Online Activism}

Zafiri's novels are noteworthy because he incorporated his migration experiences in his creative narratives. Other notable, diasporic Bidoon writers and artists include the following: Dakheel Al-Khalifa, Mohammad Al-Nabhan, Saadia Mufarreh, Kareem Al-Hazza, Mona Kareem, Zahra Marwan, Khaled Torki, Hanady Al-Shammari and Shahad Al-Fadhli. Although the writers situate themselves and conditions of statelessness differently, they concentrate on themes like identity and belonging. Much of their work has been published within the region and translated into several languages (Alshammari, 2019). Their works stress the importance of representing Bidoons through their own voices and stories. Bidoon cultural and literary works count as resistance, and oppose the ongoing silencing and censorship by the Kuwaiti authorities which shape public opinion to support their political agendas and to justify Bidoons' continuing exclusion. The government has responded with intimidation and imprisonment by silencing Bidoons who dare to speak out against their injustices and inequities.

In the last ten years, there were many attempts by Bidoon activists to organize social movements and protests to bring attention to their continuing oppression. Often the police forces Cultural and Pedagogical Inquiry, Summer 2020, 12(1), pp. 149-164 ISSN 1916-3460 @ 2020 University of Alberta http://ejournals.library.ualberta.ca/index.php/cpi/index 
reacted violently with tear gas and/or imprisonment to stop the protests (International, 2019; Beaugrand, 2014 \& 2017). In less obvious repressive practices, the Central System prohibited vocal Bidoons and their families from renewing their cards which allowed them access to services. Yet, many continue to resist and mobilize by campaigning on social networks, like Twitter, under aliases. Others protest through art and literature (Alshammari, 2019; Beaugrand, 2017; Lund-Johansen, 2014).

The collective strategies that Bidoons use to speak truth to power vary. However, all seek to humanize Bidoons and disrupt the official narratives and practices which erase their histories, and strip them of their humanity and agency. Writers like Saadia Muffareh and Khaled Torki, for example, have challenged the restricted concept of nationality that often informs and underpins the officially sanctioned works concerning Kuwaiti history and people. In his review of Bidoon literary works and Kuwaiti literary history, Tareq Alrabei (2018) analyzes Muffareh's revisionist work on Kuwaiti literature. Alrabei describes her work as a radical "intervention into the modalities of writing national history in Kuwait" (Alrabei, 2018). Muffarih's writing shifts the narrative from the official national affiliations which recognize writers and their literature based on their official national affiliations and legal categories. The official literature not only frames history within a framework of nation-states, but also situates the works of Bidoon writers intentionally at the margins. Such works are classified in dismissive terms: Adjacent Literature. The positioning of Bidoon literature as 'adjacent' reflects and reinforces Bidoon exclusion from formal, legal membership of the society. As importantly, such state strategies perpetuate and justify the very logic of Bidoon exclusion. Furthermore, Muffarih's work "undermines the nationalizing claims of past poets by stressing the unresolved tensions between a transnational past and a national present" (2018). Her work contests the very notions of national belonging that have often labelled non-citizens, like Bidoons, as being outside of the national category. Muffarih contests the state's exclusionary policies and actions by deliberately reclassifying national history within intellectual and literary affiliations that transcend the state's official national categories.

Writers like Khaled Torki, on the other hand, have concentrated on such topics as citizenship, identity and belonging in his novels to shed light on the most important issues in Kuwait. Abrar Alshammari (2019) discusses his novel "Thalatha min Al Shimal" [Three from the North] as the kind of literature that humanizes Bidoons by showing some similarities in their transnational histories and experiences with Kuwaiti citizens. His novel focuses on stories of three characters who originally derive from the North (referring to the many Bedouin tribes that now constitute the Bidoon population). Alshammari (2019) states that Torki challenges the stereotypical representations of Bidoons in Kuwaiti literature which often portray Bidoons as people who have no links to Kuwait. By highlighting their human experiences and shared lineages and heritage, Torki teaches readers that Bidoons and Kuwaitis are inextricably connected. Such literary works are important tools for Bidoons' resistance to the dominant knowledge that facilitates their continuing oppression.

Other Bidoons in the diaspora include Mona Kareem, a poet, translator and a professor in Comparative Literature. Kareem left Kuwait in 2011 to pursue citizenship and graduate education in the United States. She launched a blog that exposed the injustices committed against the Bidoon in Kuwait to international human rights media outlets. She hoped to gain support from the international community to lobby for solutions, knowing that the Bidoon in Kuwait are restricted 
from freely communicating, nationally and internationally. Eventually, Kareem had to shut the blog down because the authorities intimidated her family who remained in Kuwait. Yet, she continues to incorporate Bidoon statelessness and identity politics in her academic work.

In support of the Bidoons' right to citizenship and self-determination, Kuwaiti allies advocate knowing they face little to no risk of persecution for speaking out about the injustices the Bidoons face. However, they too face challenges. In March of 2019, shortly after Zafiri's death, there was an attempt in Kuwait to host a "Bidoon Cultural Week" to discuss their creative work and activism, racism and the impact of intergenerational statelessness on Bidoon psychology. In retaliation, the Kuwaiti authorities attempted to shut down the entire event (Alshammari, 2019). Despite the intimidation the organizers received, they held the event in an empty lecture hall at the Kuwaiti Society of Lawyers and recorded the speeches that were meant to be given at the event. The organizers then shared the recording on social media to create awareness concerning how the government silences any initiatives that expose their practises and show the truth about Bidoons' history and life in Kuwait.

With social media enabling more people to bring attention to issues that were invisible to the world for a long time, due to the monopoly over media platforms by authorities, many Bidoon activists and individuals employ Twitter as a tool for storytelling and speaking out against injustices. Some share their daily experiences dealing with the micro-aggressions of marginalization in society. Some talk about exploitation by their employers and their late salary deposits. ${ }^{2}$ Others talk about their struggles in putting their kids in schools due to very low incomes and high school fees. ${ }^{3}$ Some talk about state brutality and penalties when they try to make a living by selling merchandise on the sidewalks. ${ }^{4}$ And many more stories.

Twitter as a platform has enabled Bidoons to connect, build alliances, and share their experiences with the rest of the world. The authorities have constantly attempted to report highly vocal accounts to Twitter Support in order to shut them down and prevent them from exposing the truth. They also tracked down some account holders and attempted to charge them with criminal offenses under the Cybercrime Law that was legislated in 2015 (HRW, 2015). This law enabled the government to silence many oppositional groups by charging them and imprisoning them for tweeting their opinions about the government. ${ }^{5}$ Thus, some activists create Twitter accounts under an alias to avoid identification. Even those advocating in the diaspora are cautious about their choice of words and when they write about a specific issue to avoid being banned from entering Kuwait; or to avoid having their families, who remain in Kuwait, suffer the consequences of their activism through intimidation by the agents of the Central System.

Despite the challenges of speaking the truth in recent years there has been increasing awareness, both locally and internationally, concerning the conditions Bidoons live in. More international organizations like Amnesty International, Human Rights Watch and the Institute on Statelessness and Inclusion are involved with local and diasporic Bidoon activists. Public attention has been concentrated after an epidemic of suicides by young Bidoons who reached

\footnotetext{
${ }^{2}$ https://twitter.com/bedounplatform/status/1260657782312689664?s=20; https://twitter.com/3adeeemQ8/status/1233393272103546881?s=20

${ }^{3}$ https://twitter.com/search?q=تعليج\&src=typed query

${ }^{4}$ https://twitter.com/3adeeemQ8/status/1258365187586961413?s $=20$

${ }^{5}$ See articles: (International, 2016); (International, 2015); (ISHR, 2017)

Cultural and Pedagogical Inquiry, Summer 2020, 12(1), pp. 149-164

ISSN 1916-3460 @ 2020 University of Alberta

http://ejournals.library.ualberta.ca/index.php/cpi/index
} 
such a state of desperation, due to their atrocious living conditions (Amnesty International, 2019), which the media then frames as a result of addiction and criminal history. ${ }^{6}$ Increasing calls to end statelessness in Kuwait have come from a broader audience. It resulted from anger and frustration about the state practices that led the individuals to commit suicide. There were even protests that led to the imprisonment of fifteen vocal Bidoon activists from July 2019 until January 2020. Two activists face sentences of 10 years. One diasporic Bidoon and British citizen, judged in absentia, faces a lifetime imprisonment for protesting (Amnesty International, $2019 \& 2020$ ). Although these events helped gain attention and sympathy, there is still a need to focus efforts on structural challenges and real changes.

\section{The Significance of Naser Al-Zafiri's Novels}

What makes Zafiri's writing significant is that he was one of the few authors who wrote about the realities of migration and living in the diaspora as a Bidoon, incorporating the wider experiences of the Bidoon in and out of Kuwait. While these stories are often neglected or considered irrelevant to Bidoon politics in Kuwait, he made sure to document them in the novel. For those of us who left Kuwait looking and hoping to find acceptance, recognition and a sense of belonging, we stay connected with each other by reading the works that express experiences of exile and homelessness, especially his novels.

Zafiri was committed to sharing individual stories of Bidoons in his novels. He started writing prior to his migration and continued to do so afterwards. Some of his books have been banned in Kuwait as another measure by the government to prevent any counter narratives from reaching the public. During one of Zafiri's last visits to Kuwait, he gave a talk about his literary journey where he shared his main purpose for writing:

"I write for a specific reason. The authorities control history and select people to write a history that serves them. This history is forged. The true history is written in the novel. If you want to know the truth, you read the novel. It shows you the stories erased from those history books. If you see a glorified time period in history and you cross examine it with a novel written on the same time period, you will see what has been buried by historians and that is what makes storytelling matter in literature. The Rewayah (novel) derives from Rewayat fulan 'aw fulan' (the oral stories told over from generation to the next). And these oral stories are truths. They are sacred." - Quoting Naser Al-Zafiri during a round circle conversation organized by Majaz Cultural Group, November 30, 2016. (Quote translated from Arabic by author)

Zafiri understood novels to be oral stories that documented histories of the oppressed. He emphasized the importance of documenting the generational stories of Bidoons as they have been ignored in the past, which enabled the truth to get lost and government narratives to dominate. Despite the state's silencing and banning, Zafiri resisted by documenting the truth to rewrite history and allow future generations to refer to it to understand what happened. $\mathrm{He}$ focused on poverty, marginalization and disenfranchisement, which are struggles Bidoons continue to endure as a result of their exclusion from citizenship by the Kuwaiti government. But

\footnotetext{
${ }^{6}$ See comment on government framing: https://twitter.com/bedounplatform/status/1257055545879605250?s=20 Cultural and Pedagogical Inquiry, Summer 2020, 12(1), pp. 149-164

ISSN 1916-3460 @ 2020 University of Alberta http://ejournals.library.ualberta.ca/index.php/cpi/index
} 
he also wrote about their triumphs despite the obstacles, including migration (which is seen as a form of agency among Bidoons).

Zafiri was known for his writing and literature to be for a "noble cause", and that's how he presented himself as an author. He was asked once why he never wrote an autobiography, in which he replied: "I write my cause. What is the value of my story compared to the stories of the marginalized, those who did not have the opportunities that my family and I got?" (referring to his migration and life in Canada) (quoted in Edrees, translated by me, 2018, p. 139). He also wrote about his conceptions of Bidoons' eternal sense of exile before and after their migration, from Kuwait, by describing how the characters in his novels who migrated felt a constant struggle to belong. Nevertheless, he began to view this migration differently after he settled in Ottawa. He started to see concepts of identity, belonging and home more critically. These views were expressed more in his latest trilogy (Al-Jahra's Trilogy): Al-Mastar, Kaleeska (The Coyote), and Al-Sahed (The Scorching Heat). This resonates with how Edward Said's writing has been largely shaped by his experiences as a Palestinian in the diaspora. Said acknowledged how his diasporic life influenced the development of his views and his reading of taken for granted concepts like identity, home, and belonging. Exile created the plurality of his vision that paved the way for his secular theoretical discourses of, for example, "worldliness" which is manifested in his work.

\section{Conclusion}

Zafiri yearned for the desert that was always part of his identity as a Bedouin man, whose ancestors lived in the deserts for generations, and whose memories and childhood are shaped by the land he grew up on. Images of his burial in the cold snows of Canada triggered so many emotions for Bidoons living in the diaspora. My father told me in a conversation we recently had about Zafiri's death: "I was always fine with the idea of being buried in Canada. But after burying my friend in the snow, I have one death wish, I want to be buried in the sand." (Personal conversation, November 27, 2019). 


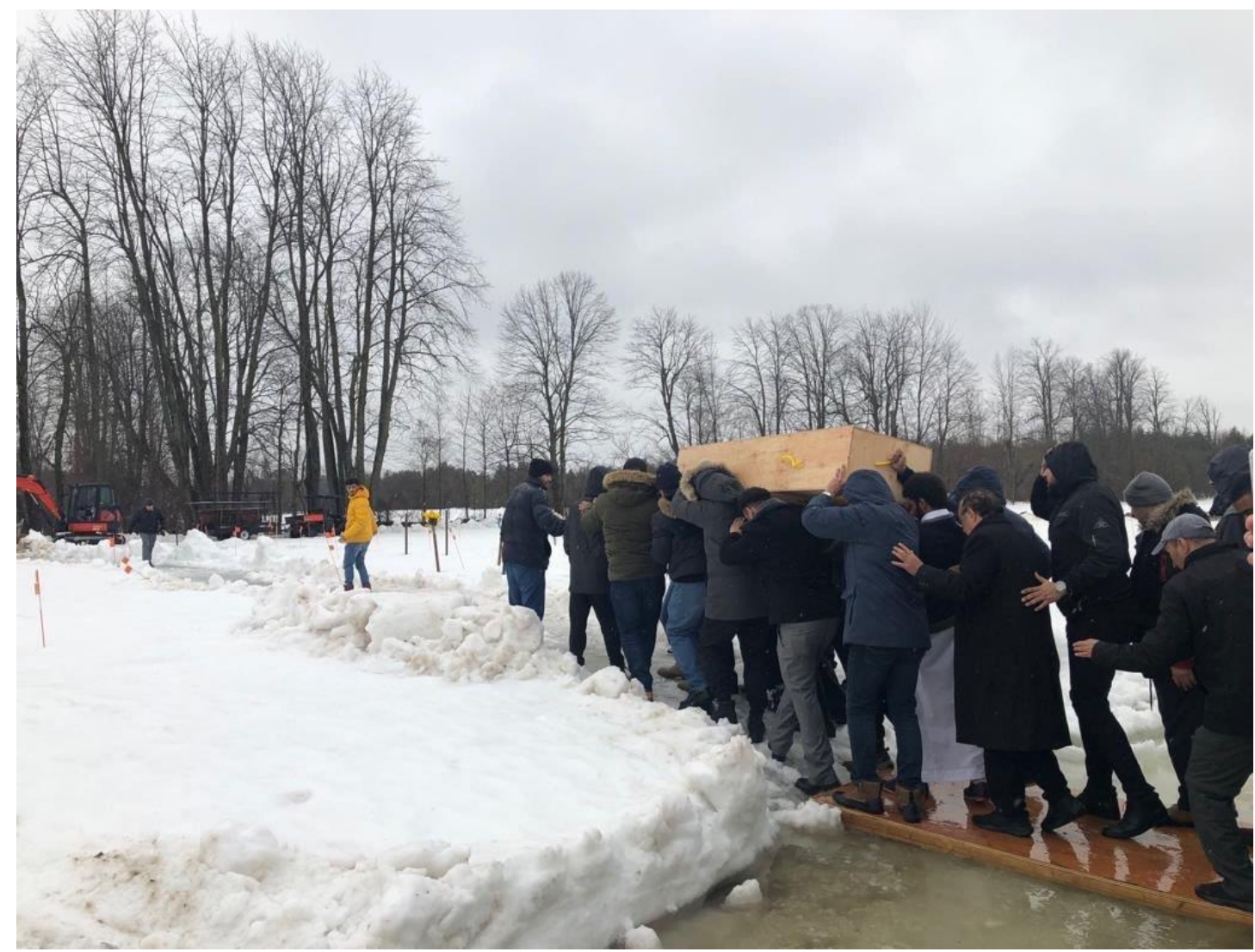

\section{Members of the Arab community in Ontario, Canada, carrying the late Naser Al-Zafiri to his grave on March 20, 2019 (Photo taken by Ali Ashoor)}

Like Maya Angelou's caged bird that sings, Bidoons - despite having their wings clipped and feet tied - choose to sing. Their voices are authentic, important ways to challenge ongoing oppression, whether in the form of online activism or writing literature. Their works are important to humanize the Bidoons themselves, to create spaces for their voices and demonstrate their agency to challenge power structures that operate in official knowledge, legislation and policies. While locally Bidoon are more heard than before, diasporic Bidoons still lack proper representation in the research and literature concerning statelessness, in general, as well as the Bidoons in particular. Zafiri's incorporation of Bidoons' migration stories was the first that I have read and felt it resonates with my experiences as a 'Bidoon-Canadian' in the diaspora. Zafiri deliberately created a third space for those of us scattered around the world, who are looking to make sense of our experiences and diasporic realities. Although Zafiri spoke from a position of a first-generation migrant who left Kuwait in his 40s, he discussed many of the same experiences of exile and homelessness that many of us feel. Zafiri devoted himself and his novels to the Bidoons' lived experiences. He wanted to center the human experiences of this community. Through his writings, he brought our realities to the forefront.

Zafiri's work continues to have an impact on the Bidoons as it connected us across space and time. His work motivated me to write more about my experiences as a diasporic Bidoon. I feel it is my responsibility to document these stories and continue this work. Zafiri's exilic 
identity, like Edward Said's, exemplifies a powerful transformation from losing a home into becoming highly respected intellectuals. This work transcends the national boundaries of space and time, and challenges the dominant frameworks of identity and belonging. Leaving Kuwait never meant that Zafiri stopped speaking truth to power; he proved it in his novels. Said's ground-breaking work has challenged the canon in the social sciences and humanities. While exile was a cause for sorrow in Said's life, he pointed out that "the sense of loss is both deep and unremitting, but it is a sense of loss from which empowerment emerges" (Baboun, 2012). Edward Said never resigned himself to silence. Instead, as a scholar, he mastered the abilities to speak and write the truth to power. Despite the barriers I addressed above, Naser Al-Zafiri and all other Bidoon writers and activists mastered speaking truth to power. As Maya Angelou (1983) wrote about the bird that sings for freedom:

\author{
"But a bird that stalks \\ down his narrow cage \\ can seldom see through \\ his bars of rage \\ his wings are clipped and \\ his feet are tied \\ so he opens his throat to sing."
}

(Angelou, 1983, p. 154) 


\section{References}

ADHRB. (2019, September 3). HRC42 Written Statement: Kuwait's UPR: Systematic Human Rights violations and the ongoing targeting of the Bidoon. Retrieved from ADHRB: https://www.adhrb.org/2019/09/hrc42-written-statement-kuwaits-upr-systematic-humanrights-violations-and-the-ongoing-targeting-of-the-bidoon/

Alhajeri, A. M. (2015). ‘The Bedoun': Kuwaitis without an Identity. Middle Eastern Studies.

Alrabei, T. (2018). Bidun Poets and Kuwaiti Literary History. Journal of Arabian Studies: Arabia, the Gulf, and the Red Sea, 8(2), 193-207.

Alshammari, A. (2019, December 2). The Rise of Bidun Literature: Representation and Advocacy in Kuwait. Retrieved from The Arab Gulf States Institute in Washington: https://agsiw.org/the-rise-of-bidun-literature-representation-and-advocacy-in-kuwait/

Angelou, M. (1983). Shaker, Why Don't You Sing? New York: Random House.

Baboun, V. G. (2012, April 6). Edward Said: A Mentor Who Mastered Speaking Truth To Power. Retrieved from Fondazione Giovanni Paolo 2: https://www.fondazionegiovannipaolo2.org/?p=245

BBC. (2020, January 31). لماذا وصف وفد الكويت بـ "الكاذب" بعد جلسة مجلس الأمم المتحدة لحقوق الإنسان؟.

Beaugrand, C. (2014). Framing Nationality in the Migratory Context: The Elusive Category of Biduns in Kuwait. Middle East Law and Governance, 6(3), 173-203.

Beaugrand, C. (2017). Stateless in the Gulf: Migration, Nationality and Society in Kuwait. London/ New York: I.B. Taurus.

Belton, K. A. (2015). Rooted displacement: The paradox of belonging among stateless people. Citizenship Studies, 19(8), 907-921.

Bloom, H. (1996). Maya Angelou's I Know Why the Caged Bird Sings. New York: Chelsea House Publishers .

Cole, P. (2019). Taking Statelessness Seriously. Statelessness and Citizenship Review, 1(1), 161-164.

Eldemerdash, N. (2015). Being and Belonging in Kuwait: Expatriates, Stateless Peoples and the Politics of Citizenship. Anthropology of the Middle East, Volume 10, Issue 2, 83-100.

HRW. (1995). The Bedoons of Kuwait: "Citizens without Citizenship". Human Rights Watch.

HRW. (1995). The Bedoons of Kuwait: "Citizens without Citizenship". New York, Washington, Los Angeles, London, Brussels: Human Rights Watch.

HRW. (2015, July 22). Kuwait: Cybercrime Law a Blow to Free Speech: Extends Problematic Press Provisions to Online Expression. Retrieved April 2020, from hrw.org: https://www.hrw.org/news/2015/07/22/kuwait-cybercrime-law-blow-free-speech 
International, A. (2015, December 14). Kuwait at risk of sliding into deeper repression amid growing clampdown on critics. Retrieved April 2020, from amnesty.org: https://www.amnesty.org/en/latest/news/2015/12/kuwait-at-risk-of-sliding-into-deeperrepression-amid-growing-clampdown-on-critics/

International, A. (2016, December 5). GCC summit: Systematic clampdown on freedom of expression in Gulf. Retrieved April 2020, from amnesty.org:

https://www.amnesty.org/en/latest/news/2016/12/gcc-summit-systematic-clampdown-onfreedom-of-expression-in-gulf/

International, A. (2019, July 17). Kuwait: Authorities crackdown on protesters demanding citizenship rights. Amnesty International. Retrieved from:

https://www.amnesty.org/en/latest/news/2019/07/kuwait-authorities-crackdown-on-protestersdemanding-citizenship-rights/

International, A. (2020, January 28). Kuwait: Heavy prison sentences of activists demanding rights of citizenship. Retrieved April 2020, from amnesty.org:

https://www.amnesty.org/en/latest/news/2020/01/kuwait-heavy-prison-sentences-of-activistsdemanding-rights-of-citizenship/

ISHR. (2017, January 31). Kuwait | End crackdown on freedom of expression and women human rights defenders. Retrieved April 2020, from International Service for Human Rights: https://www.ishr.ch/news/kuwait-end-crackdown-freedom-expression-and-women-humanrights-defenders

ISI. (2018). Statelessness in numbers: 2018 An overview and analysis of global statistics. Institute on Statelessness and Inclusion. URL: https://files.institutesi.org/ISI_statistics_analysis_2018.pdf

Kingston, L. (2019). Expanding Statelessness Scholarship: The Value of Interdisciplinary Research and Education. Statelessness and Citizenship Review, 1(1), 165-169.

Lund-Johansen, M. B. (2014). Fighting for Citizenship in Kuwait (MA Thesis). Retrieved from: https://www.duo.uio.no/handle/10852/43302 Oslo: University of Oslo.

Rainbow, P. (1991). The Foucault Reader: An Introduction to Foucault's Thought. London: Penguin.

Sazzad, R. (2017). Spanish / English / Edward Said's Concept of Exile: Identity and Cultural Migration in the Middle East. I. B. Tauris.

Siddiqi, D. (2019, May). Weaponizing Paperwork: Rohingya Belonging and Statelessness. Retrieved May 2019, from thedailystar.net: https://www.thedailystar.net/in-focus/news/weaponisingpaperwork-rohingya-belonging-and-statelessness-1739416

Thapan, M. (2005). Introduction: 'Making Incomplete': Identity, Woman and the State. In M. Thapan, Transnational Migration and the Politics of Identity (pp. 23-62). New Delhi, Thousand Oaks, London: SAGE Publications.

UNHCR. (2014). Global Action Plan to End Statelessness: 2014-2024. Retrieved from: www.unhcr.org/uk/protection/statelessness/54621bf49/global-action-plan-end-statelessness2014-2024.html

Cultural and Pedagogical Inquiry, Summer 2020, 12(1), pp. 149-164

ISSN 1916-3460 @ 2020 University of Alberta

http://ejournals.library.ualberta.ca/index.php/cpi/index 